\title{
The dynamics of the development of harmful insects on the mother planting of basic grape plants in the Rostov region
}

\author{
Natalia Arestova ${ }^{1}$, and Irina Ryabchun ${ }^{1 *}$ \\ ${ }^{1}$ All-Russian Research Ya. I. Potapenko Institute for Viticulture and Winemaking» - Branch of the \\ Federal State Budget Scientific Institution «Federal Rostov Agricultural Research Centre»; \\ 166 Baklanovsky prospect, Novocherkassk, 346421, Russia
}

\begin{abstract}
The study results on prevalence of the main harmful insects on the mother planting of the basic grape plants of the Rostov region: rose leafhopper, buffalo treehopper, tree cricket, tobacco and grape thrips, which are polyphagous phytophages, are presented. As a result of the negative impact of harmful organisms the plant normal development is disrupted. The spread and increase in the insect harmfulness in the Rostov region is facilitated by an increase in the average annual temperature to $9.5-11.6^{\circ} \mathrm{C}$ in the last 10-15 years, which is the lower limit for their survival. A close direct relationship was revealed between the average annual temperature and the leafhopper and thrip harmfulness: $r=0.72-0.89$ and an unobvious dependence of the tree cricket harmfulness on thermal conditions $(\mathrm{r}=0.59)$. The phytosanitary control system in the mother planting made it possible to restrain the harmful organism development, with a harmfulness not exceeding 1.3 points for thrips and 2 points for other insects for further reproduction of practically healthy grape planting material while maintaining the status basic plants.
\end{abstract}

\section{Introduction}

Vineyards can be hosts of various phytophages that negatively affect plants directly or indirectly. They eat plant organs and can also be carriers of fungal, viral and phytoplasmic diseases [1]. The deterioration of the state of the vineyards is noted due to their infection with viruses and phytoplasmas. According to literary sources, it is known that about $40 \%$ of vineyards in European countries are at risk of infection, due to the increase in the number of harmful insects on vine plantations [2]. On the mother planting of grape plants, the harmful effects of insects are aggravated by the fact that plantations can be infected with quarantine phytopathogens [3].

A fairly large number of pests live on vine plantations that negatively affect the plant, however, only some of them can cause significant harm. These are mainly insects, mites and nematodes.

\footnotetext{
*Corresponding author: ruswiner@mail.ru
} 
In European vineyards, significant economic damage is caused by leafhoppers, scale insects, thrips, beetles, aphids, mites, etc. One of the most dangerous leafhopper for the grapevine is the North American leafhopper (Scaphoideus titanus), which transmits the golden yellowing phytoplasm of the leaf Candidatus Phytoplasma vitis.

Each species adapts to specific environmental conditions. Changing climatic factors lead to the expansion or reduction of the range of certain harmful insects. The interaction of a complex of factors of different nature leads to a change in the degree of harmfulness of living organisms in the composition of agrocenoses, which has been observed in recent years. There have been changes in the distribution and harmfulness of many harmful objects caused by climate warming, changes in economic activities and disruption of the natural vegetation cover. Some species have lost their economic importance, while others have settled, having mastered new territories $[4,5]$.

The most common harmful insects in the ampelocenosis of Rostov region vineyards are grapevine phylloxera (Viteus vitifolii Fitch), different types of leafhoppers: Ceresa alta Walker - buffalo treehopper; Edwardsiana rosae - rose leafhopper; Oecanthus pellucens stem cricket (trumpeter); Drepanothrips reuteri - grape thrips; Thrips tabaci - tobacco thrips [6].

Leafhoppers (Hemiptera: Cicadellidae) are dangerous pests in vineyards in temperate climates. Around 21,000 species have been found worldwide. There is a wide variety of leafhoppers found in the vineyard. Canadian scientists have identified 110 species of leafhoppers in commercial vineyards in three main provinces, with 22 species dominating, their number was $91 \%$. The prevalence of one or another type of leafhoppers depends, among other things, on the plants surrounding the vineyard, among which are weeds and cultivated herbaceous plants. These plants can host several species of leafhoppers and are a reservoir of pathogens such as phytoplasma or viruses, which can sometimes be transmitted to the vine [7].

Buffalo treehopper (Ceresa alta Walker) was discovered in the 19th century in North America. Now distributed throughout Europe, found in Asia. In the Rostov region, a tangible negative impact on the grape plant of this pest has been noted since 2004. Vitis vinifera grape varieties are more affected by Ceresa alta Walker. The pest makes cuts on the green shoot, causing injury and death of the shoots. Symptoms are less severe on hybrid grapes.

Rose leafhopper (Edwardsiana rosae) along with grape leafhopper (Empoasca vitis) is considered the main pest in vineyards in European countries. It infects the leaves of grapes, which leads to the appearance of whitish and silvery spots on the leaves. A large number of leafhoppers can lead to the death of all leaves on the shoot. In addition, the excrement left by rose leafhoppers on grape fruits requires special cleaning [8]. In the Rostov region, rose leafhopper was discovered in 2007.

The tree cricket Oecanthus pellucens until recently was widespread in the Mediterranean countries, but due to the warming of the climate, it has moved to colder countries. Its habitat is meadow fields with high vegetation. The stem cricket prefers to lay eggs on the shoots of grapes, causing deep punctures, therefore the alternative name of the pest in Europe is wine cricket. In the Rostov region, the pest was recorded in 2004. The most damaged were plantations adjacent to forest belts. The greatest damage to young growing organs of grapes in late spring - early summer is caused by herbivorous thrips found on the mother planting of basic plants, especially affecting buds, leaves, flowers. The leaves damaged by thrips necrosis, which affects the deterioration of plant nutrition and their growth activity [9].

Due to climate change, significant changes are possible in the rates of development, survival and reproduction of phytophages in the vineyard. On this score, there are conflicting opinions, as some scientists argue that periods of extreme heat in the summer months and higher temperatures in winter will inhibit the growth and development of harmful insects [10.11]. Other scientists argue that with a warming climate, especially in temperate latitudes, 
there will be a significant increase in the population of harmful insects, and the degree of their negative impact on the plant due to the growth rate of the population and a significant increase in the metabolic rate of insects. It is also noted that in tropical regions the growth rates of populations of harmful insects will significantly decrease, in contrast to temperate latitudes [12-13]. In our conditions, pest control in the mother planting presupposes a special system for monitoring the development and spread of harmful organisms and protection against them. In this case, the main attention is paid to measures to prevent the penetration of these organisms into the territory of the mother planting. The solution to this problem is primarily achieved by observing quarantine measures, as well as preventing the emergence of foci of the development of harmful organisms through timely treatment of plantations with effective pesticides, as well as biological measures. $[14,15]$. The purpose of our research was phytosanitary monitoring of the development and spread of pests, especially those contributing to the spread of viral diseases and the implementation of protective measures to prevent the spread of pests.

\section{Materials and methods}

The studies were carried out in the Rostov region on the mother plantings of improved plants from 2015 to 2019. Monitoring of the development, distribution and harmfulness of phytophages was carried out, various schemes for protecting grape plantations on the mother planting were studied. The set of measures to protect against harmful organisms also includes a disinfection barrier, which prevents their spread with the help of technology and people. Control over pests-vectors of infection is carried out by various methods: regular monitoring of the adjacent zone of spatial isolation $(50 \mathrm{~m})$ in order to identify and prevent the development of foci of pests-vectors of viruses dangerous for grapes; preventive treatments of plantings and the adjacent zone of isolation from pests. The work used the generally accepted methods of phytosanitary monitoring and control of pests in the vineyard. To regulate the number of phytophages, insecticides from the "List of pesticides and agrochemicals permitted for use on the territory of the Russian Federation" were used.

\section{Results and discussion}

Among the harmful insects common on the mother planting of basic plants, the buffalo treehopper was identified, causing significant harm to plants. When nutrition, the buffalo treehopper damages the tissues of the phloem and cambium with numerous injections, leading to deformation of the cortex in the form of ring-shaped interceptions and swelling of tissues.

As a result of injections of the buffalo treehopper and damage to the bark of the shoots, the processes of their nutrition, growth and development are disrupted. The external manifestation of damage to plants by the buffalo treehopper is, in addition to visible interceptions on the shoot, twisting of leaves and their premature staining.

The imago and larvae of the rose leafhopper suck out the leaf juice from the underside. This results in marble spots on the upper side of the leaf and white remnants of larval integuments on the lower side (Fig. 1).

As a result of damage caused by rose leafhoppers, necrosis and deformation of the leaves is observed. Due to this, the synthesis of organic substances in the leaves deteriorates, and, accordingly, the nutrition of plants. Thus, in case of severe damage to plants by the pest, a decrease in the productivity of plantations is often observed. Protective measures against rose leafhoppers are most effective during the larval stage, since adults are more resistant to insecticides. 


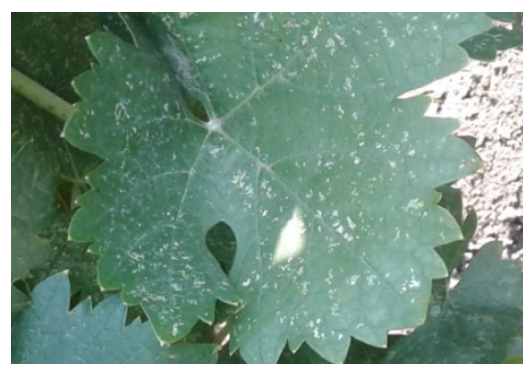

Fig. 1. Discoloration of leaves as a result of pricks of the rose leafhopper

In the conditions of the Rostov region, grape plants have become hosts for the polyphagous pest - the common tree cricket (trumpeter) since 2005. The main harm is the cricket brings grape plants during egg-laying, during which the female insect damage the green shoots that dry out above the damaged areas. Pests lay eggs in groups of 2-4, of which larvae appear in late June-early July. Damage to the shoots by the tree cricket results in a violation of the growth and maturation of the shoots, which negatively affects the quality of the harvested vine.

On grape plants of some varieties, damage is revealed by thrips: grape (Drepanothrips reuteri); tobacco (Thrips tabaci) (Fig. 2).

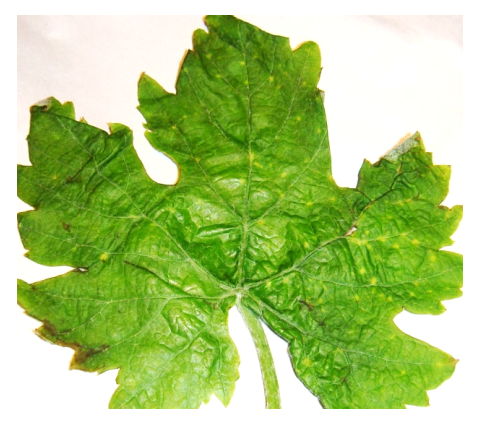

Fig. 2. Thrips bites on leaves

The most vulnerable to the pest are grape plants in spring, during the period of active growth of all organs. By feeding on plant sap, the pest can carry viral diseases.

The prevalence and harmfulness of insects varied by year with maximum values n 2016 and 2018 (table).

Table Dynamics of harmfulness of insects (points) by years

\begin{tabular}{|l|c|c|c|c|}
\hline \multirow{2}{*}{$\begin{array}{c}\text { Year of the } \\
\text { research }\end{array}$} & \multicolumn{4}{|c|}{ Insect harmfulness, score } \\
\cline { 2 - 5 } & Oecanthus pellucens & Typhlocyba rosae & Ceresa bubalus & Thrips \\
\hline 2015 & 1 & 1.3 & 2.0 & 1.1 \\
\hline 2016 & 1.8 & 1.5 & 1.9 & 1.3 \\
\hline 2017 & 0.6 & 1.0 & 0.8 & 0.9 \\
\hline 2018 & 1.5 & 1.4 & 1.9 & 1.2 \\
\hline 2019 & 1.9 & 1.2 & 1.8 & 0.8 \\
\hline
\end{tabular}

Analysis of the influence of average annual temperature on the harmfulness of insects revealed a close correlation between them (Fig. 3) 


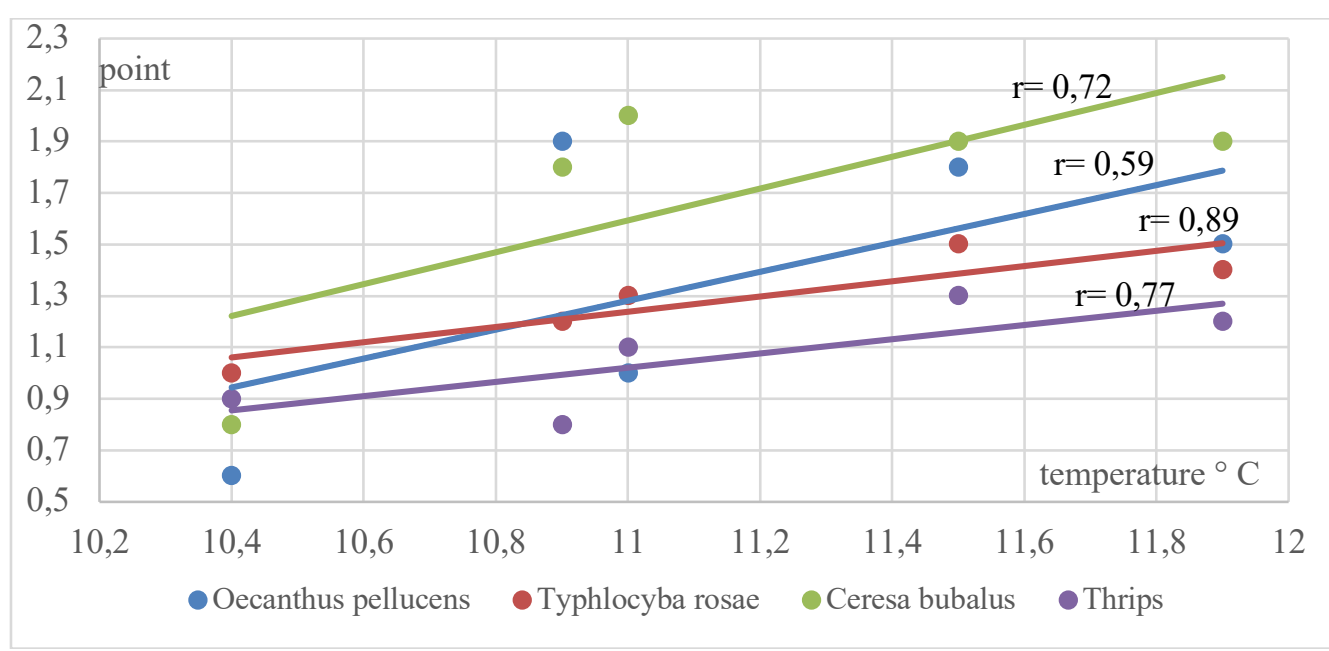

Fig. 3. Influence of the average annual temperature on the harmfulness of insects

The experimental data obtained indicate the relationship between the average annual air temperature and the degree of damage to grape plants by harmful insects. With an increase in temperature, the harmfulness of leafhoppers and thrips significantly increases $(r=0.72$ 0.89 ), the relationship between the annual thermal stress and the harmfulness of the tree cricket is not so obvious - $r=0.59$.

Harmful insects found on the mother planting are dangerous for improved plants with the possibility of secondary infection with quarantine diseases. In this regard, protective measures include not only treating plants with insecticides, but also maintaining a disinfection barrier. When drawing up the protection scheme, we were guided by the principle of rotation of active substances and using an active substance of the same name no more than twice a season. The following classes of pesticides were used Juvenoids: Fenoxycarb; Pyrethroids: Lambda-cyhalothrin, Deltamethrin, Alpha-cypermethrin, bifenhtrin; Oganophbsphorus comp: Malathion, Chlorpyrifos, Phosalone, Dimethoate; Neonicotinoid Thiamethoxam.

\section{Conclusion}

The main harmful insects on the mother planting of basic plants are buffalo treehopper; rose leafhopper, thrips; tree cricket.

Research confirms the influence of meteorological conditions on the harmfulness of insects. A positive correlation-regression dependence was revealed between the average annual temperature and harmfulness with a correlation coefficient $r=0.72-0.88$ for leafhoppers and thrips and $\mathrm{r}=0.59$ for cricket.

The system of phytosanitary control over in vitro improved plants under the conditions of the mother planting of basic plants made it possible to restrain the development of harmful organisms, with a harmfulness not exceeding 1.3 points for thrips and 2 points for other insects, thereby ensuring further reproduction of practically healthy planting material of grapes with maintaining the status of basic plants.

\section{References}

1. M. Kölber, Intern. J. Horticul. Sci., 17(3), 37-43 
https://doi.org/10.31421/IJHS/17/3/955

2. N.J. Bostanian, C. Vincent, R. Isaacs, In: Anthropod Management in Vineyards (Springer, 2012) https://doi.org/10.1007/978-94-007-4032-7

3. H Waite, M Whitelaw-Weckert, P Torley, N. Zealand J. Crop Hortic. Sci., 43(2), 144161 (2015) https://doi.org/10.1080/01140671.2014.978340

4. J.K. Chen, R. Hill, D.B. Ohlemüller, C.D. Roy, Science, 333, 1024-1026 (2011) https://doi.org/10.1126/science. 1206432

5. M. C. Sgrò, S. J. Terblanche, A. Rev. Entomol, 61(1), 433-451 (2016) https://doi.org/10.1146/annurev-ento-010715-023859

6. N.O. Arestova, I.O. Ryabchun, BIO Web Conf., 25, 06001 (2020) https://doi.org/10.1051/bioconf/20202506001

7. J. Saguez, C. Olivier, A. Hamilton, T. Lowery, L. Stobbs, J. Lasnier, B. Galka, X. Chen, Y. Mauffette, C. Vincent, J. Insect Sci., 14(1), 73 (2014) https://doi.org/10.1093/jis/14.1.73

8. A. Reineke, M. Hauck, J. Appl. Entomol., 136(9), 656-664 (2012) https://doi.org/10.1111/j.1439-0418.2011.01699.x

9. A. N. Moreira, J. V. D. Oliveira, J. E. D. M. Oliveira, J. B. Torres, G. M. M. D. Souza, S. M. D. Rev. Bras. Frutic. 39(5), e-582 (2017) https://doi.org/10.1590/010029452017582

10. H. Colinet, BJ. Sinclair, P. Vernon, D. Renault, Ann. Rev. Entomol., 60, 123-140 (2015) https://doi.org/10.1146/annurev-ento-010814-021017

11. B. Bois, S. Zito, A. Calonnec, OENO One, 51(2), 133-139 (2017) https://doi.org/10.20870/oeno-one.2017.51.2.1780

12. C.A. Deutsch, J.J. Tewksbury, M. Tigchelaar, D.S. Battisti, S.C. Merrill, R.B. Huey, R.L. Naylor, Sci., 361, 916 (2018) https://doi.org/10.1126/science.aat3466

13. A. Reineke, D.Thiéry, J. Pest Sci., 89, 313-328 (2016) https://doi.org/10.1007/s10340016-0761-8

14. J.M. Reiff, S. Kolb, M.H. Entling, T. Herndl, S. Möth, A. Walzer, M. Kropf, C. Hoffmann, S. Winter, Insects, 12(3), 220 (2021) https://doi.org/10.3390/insects12030220

15. L. J. Thomson, A. A. Hoffmann, Bio. Control, 64(1), 57-65 (2013) https://doi.org/10.1016/j.biocontrol.2012.09.019 